UDC 657.6

DOI: https://doi.org/10.30839/2072-7941.2018.149678

\title{
INTERNAL AUDIT AND CONTROL IN A COMPANY IN THE CONTEXT OF MANAGEMENT ACTIVITY
}

\author{
(C) GABREVIČIENE், AUŠRA
}

Lecturer, Marijampolè College (Marijampolè, Lithuania)

E-mail: ausra.gabreviciene@ mkolegija.It, ORCID 0000-0001-7685-1440

\section{PETROŠIENE், BIRUTE்}

Lecturer, Marijampolè College (Marijampole, Lithuania)

E-mail: birute.petrosiene@ mkolegija.lt, ORCID 0000-0002-5160-8249

\author{
(C) ŠIDLAUSKIENE், DANGUOLE் \\ Lecturer, Master of Science, Marijampolè College (Marijampolè, Lithuania) \\ E-mail: danguole.sidlauskiene@mkolegija.lt, ORCID 0000-0002-9154-2934
}

\begin{abstract}
Entities pursuing their objectives focus on the smooth and efficient operations and processes, and optimum use of funds. For this purpose, an internal control system is being implemented in enterprises and organizations, one of the components among these systems is internal audit. The main objective of the internal auditor is to provide an independent and impartial assessment of the entity's performance and provide insights on how to improve its operations. Although internal audit is only part of the internal control system of the entity, it has to assess the proper functioning of the system itself, propose measures to make internal control more efficient. The state of internal control largely depends on the work of the internal auditor. Scientific problem. The scientific literature emphasizes the need to create an appropriate system of internal control of the entity, but for many supervisors and internal auditors internal audit and internal control still associate with the role of the inspector. A well-functioning internal control system reduces the work involved in the audit and risks that allow the internal auditor to devote more time to developing the entity's development prospects. Particular attention in the process of operational efficiency must be given to employees performing the functions entrusted to them, including them in the process of internal control improvement. Not only managers but also all employees need to deepen knowledge of the importance of internal audit and the necessity of reaching the goals set by the entity, not only managers but also all employees. The aim of the article: to analyze peculiarities of theoretical internal audit and control. In order to achieve the tasks: to analyze the concept of internal audit and control, and its variation; to research internal audit objectives. The object of the research: internal audit and control in a company. The methodology of the research: the systemic analysis of scientific literature and legislation.
\end{abstract}

Key words: internal audit, internal control system, activity, entity, adding value.

INTRODUCTION

Relevance of the topic. Currently in Lithuania the function of internal audit is mandatory in all public and financial companies. Internal audits are also mandatory for those companies whose securities are traded on exchanges. In the remaining private equity firms, the decision on the need for internal auditing depends on the management's approach to the internal audit function. It is customary in achieving predefined goals to focus on the fluidity and efficiency of the 
operations and processes, and on the optimal use of resources. However, managers not always are successful in spotting risks or problems that have negative impact on business development. Therefore, it is very important to have well matched manager's view to the meaning and necessity of internal audit in the process of adding value.

Internal control is an integral part of internal audit, therefore it is very important to understand the significance of the internal control system in both large and small to medium enterprises. Rapid technological development and economic change force corporate leaders to change their attitudes about internal control, because only efficient control can ensure the achievement of the company's stated goals. Surveys show that most executives understand the need of internal control system for an enterprise but not all of them know the basic principles of creating internal control system. Quite often it appears that an internal control system is created only formally to provide desired corporate image, but in reality, internal control system does not function. Only a well-functioning, efficient and professional internal control system can give a company noticeable benefits not only in responding to risk factors, but also by saving resources. Properly designed and functioning internal control system allows the entity to solve problems in an innovative way and thus increase its competitiveness. Therefore, it is very important to constantly analyze the peculiarities of internal audit and control of companies, both theoretically and in practice.

Scientific problem. The scientific literature emphasizes the need to create an appropriate system of internal control of the entity, but for many supervisors and internal auditors internal audit and internal control still associate with the role of the inspector. On the speed of adaptability to the changes of environment, depends the success of business, thus managers and internal auditors need to be able to use modern tools for business and business management. Internal audit largely determines the proper functioning of internal control, and therefore the problem is to separate internal audit function from other functions within the entity.

The aim of the article: to analyze peculiarities of theoretical internal audit and control.

In order to achieve the tasks: to analyze the concept of internal audit and control, and its variation; to research internal audit objectives.

The object of the research: internal audit and control in a company.

The methodology of the research: the systemic analysis of scientific literature and legislation.

\section{THEORETICAL ASPECTS OF INTERNAL AUDIT AND CONTROL}

In practice, internal audit is understood as an effective and qualified tool for managing an entity, and control which is necessary in order to ensure the rational use of the property and its security. In the scientific literature and legislation, 
internal audit is defined more broadly, focusing not only on accounting matters but also on business strategies and plans, changing the global economic, social and political situation.

The Law on Internal Control and Internal Audit of the Republic of Lithuania [6] describes internal audit as part of the internal control system, which, by means of independent and objective assessment and consulting activities of internal auditors, is aimed at ensuring the improvement of the activities of an entity.

In assessing the evolution of internal audit, the self-governing organization of the largest professional internal audit activity, the International Institute of Internal Auditors published a definition of internal audit reflecting a new approach to the role of internal auditor in the organization. It states that "Internal Audit is an independent and objective inspection and consulting activity aimed at assessing and improving the performance of the entire organization. The purpose of internal audit is to systematically and comprehensively assess, promote and improve the effectiveness of the organization's risk management, control and oversight processes, and contribute to meeting the organization's objectives [10].

V.Lakis [5] describes the internal audit as an independent activity (function) within an entity that examines the internal control system and the quality of the activity to help management make decisions. In practice, internal audit examines not only the state of accounting and control, but also the efficiency of the operations of the entities of the entity and the compliance of their activities with the general policy, consulting activities.

R.Rupšys and V.Boguslauskas [9] emphasize risk management when defining internal audit. In their view, internal audit is an active function within an entity that includes inspection and consulting services, while creating added value through a structured and systematic approach that enables us to evaluate and improve the effectiveness of risk management, control and supervision processes.

Pickett [8] defines internal audit as an independent assessment function within an entity that includes an examination and assessment of the adequacy and effectiveness of internal control.

By analyzing the definitions of internal audit provided by researchers, it can be concluded that they increasingly emphasize the systematic nature of the audit, focusing on the entity's management system, in particular on the efficiency of internal control and on risk management. Most of them emphasize the advisory function, and this is understandable, since internal audit activity is increasingly concentrated not only in accounting matters, but also includes business strategy and plans. Summarizing the ideas of scientists, it can be stated that today's internal audit is the process of obtaining, analyzing and evaluating objective data on economic events. The audit assesses the performance of the entity and presents the results to executives. At the same time, these are independent and objective guarantees 
and advisory services aimed at assessing the suitability and efficiency of an entity's internal control system, achieving its objectives and adding value.

Having analyzed the concept of internal audit, it is important to clarify the relationship between internal audit and internal control of an entity. Managers need to create an effective internal control system, with internal control as one of its components, in order to ensure effective leadership and achieve the intended business objectives. The volume of internal audit work depends on the entity's internal control system as it examines the adequacy and effectiveness of the internal control system. For internal audit, it is important to establish that the internal control system not only works, but also guarantees the achievement of the entity's objectives. To this end, internal audit assesses and demonstrates how the internal control system works, identifies its weaknesses and submits management suggestions on how to improve it.

A prerequisite for assessing the internal control system is the analysis and interpretation of the concept of internal control. With constant changes in the scope, functions and roles of internal control, it is important to formulate a common definition of internal control and to identify the place of internal control in an entity [1]. It is even more important to foresee measures for the implementation of the internal control system and their effectiveness evaluation.

Definition of internal control as a separate entity system for the first time in 1949. presented by the
American Certified Accountants Institute (AICPA), which indicated that internal control is a plan for the company and all other coordinated measures and methods whose main function is to safeguard the entity's assets, verify the correctness and accuracy of the data, increase the efficiency of operations and guarantee the intended management policy [1]. This definition has been continuously improved and now it indicates that the internal control system is one of the tools of the management to ensure active security and sustainable development.

King [4] defines internal control as a process that seeks to achieve the goals of the company, and at the same time the result of the planning, organization and monitoring of the company's management activities is the result of the whole enterprise and its departments.

Needles and others [7] have been monitoring internal control by the company's administration's control system to help you manage your business properly in accordance with the strategy, secure your assets, rational utilization, completeness and accuracy of your accounting data.

In the view of DiNapoli [2] internal control is a process, affected by an entity's board of directors, management, and other personnel, designed to provide reasonable assurance regarding the achievement of objectives relating to operations, reporting, and compliance.

In practise, some specialists of audit and accounting identify the internal control system and internal audit. Accoding to R. Kanapickiene [3], sometimes there may be 
uncertainty as it is assumed that internal audit can't be an integral part of the internal control, because it assesses the internal control itself. However, excluding internal audit from the entity's internal control system, this system can turn into an open, non-feedback management system. The purpose of internal audit is to check and evaluate the internal control system, to determine effectiveness and deficiencies of certain procedures, to monitor that these procedures are not violated and comply with the rules approved by the management. The internal audit service must inform the management of the entity if violations detected or possible ways of strengthening internal control are identified. The link between the internal control system and the internal audit is that the internal audit service is classified to the main structural units of the entity, most of which particular the internal control system, especially an environment and procedures of internal control. Other departments include accounting and departmental technology.

The conclusion is that internal audit is not a specific supplement to the activities of the entity. It is basis not for only establishing proper internal control, but also for ensuring its effective operation. However, the work of the internal auditor largely depends from the state of internal control of the entity. The wellfunctioning internal control system reduces the amount of the internal auditor and risk. This enables for internal auditor to devote more time for entity's development prospects.

\section{OBJECTIVES OF INTERNAL AUDIT AND CONTROL}

Both the International Standards for Internal Audit Professional Practice and the scientific literature emphasize that internal audit is an independant form of control thats acts within the entity in accordance with the principles of management's policies. Having analyzed the concept of internal audit, three main charactetistics of internal audit can be distinguished:

- independence of the internal auditor;

- checking and evaluating the efficiency of the entity's activities;

- assistanse for the entity's employees to improve their operarions.

Based on the distinguished features, it is possible to formulate the main objective of internal audit - to examine and evaluae the activities of the entity, its internal control system, and to provide an assistance for management personnel in improving their functions.

In the view of DiNapoli [2] there are three types of objectives which emphasize differing aspects of internal control:

- Operations Objectives pertaining to effectiveness and efficiency of the entity's operations, including operational and financial goals. These objectives promote orderly, economical operationsand hepl produce quality products and services consistent with the organization's mission. They also serve to safeguard resources against loss due to waste, abuse, mismanagement, errors and fraud. 
- Reporting Objectives - relating to internal and external financial and nonfinancial reporting. These objectives may encompass reliability, timeliness, transparency, or other terms as set forth by regulators, recognized standard setters, or the organization's policies.

- Compliance Objectives dealing with adherence to laws, regulations, contracts and management directives to witch the entity is subject.

In the view of the above objectives, one can conclude, that every member of an organization has a role in the system of internal control. The human factor is critical to the system's success [2]. Internal controls are developed by people, guide people, and provide them with means of accountability. People are responsible for implementing each element of the system properly. Individual roles in the system of internal control vary greatly throughout an organization. Very often, an individual's position in the organization determines the extent of that person's involvement in internal control.

It is necessary to ensure that each of the entity understands himself as responsible for the effectiveness of the internal control system. Only then can expect a positive attitude towards the internal audit function of the organization. To this end, it is necessary to constantly examine not only the manager's knowledge, but also the the knowledge of all employees about internal audit and explain how much they can benefit from internal control and what they can expect from an internal auditor.

\section{CONCLUSIONS}

1. Internal audit is not a specific supplement to the activities of the entity. It is basis not for only establishing proper internal control, but also for ensuring its effective operations. However, the work of the internal auditor largely depends from the state of internal control of the entity. The well-functioning internal control system reduces the amount of the internal auditor and risk. This enables for internal auditor to devote more time for entity's development prospects.

2. The main objective of internal audit is to examine and evaluae the activities of the entity, its internal control system, and to provide an assistance for management personnel in improving their functions.

3. It is necessary to ensure that each entity itself aknowlages and evaluates the need for the effectiveness of the internal control system. Only then it can expect a positive attitude towards the internal audit function in the organization. To this end, it is necessary to constantly examine not only the manager's knowledge, but also the the knowledge of all employees about internal audit and explain how much they can benefit from internal control and what they can expect from an internal auditor.

\section{REFERENCES}


1. Daujotaitè, D., Giriūnas, L., Giriūnienè, G., Miškinis, A., Adomavičiūtè, D., Vinauskienė, D. (2015). Finansų kontrolè ir auditas: teorija ir praktika. Vilnius: Mykolo Romerio universitetas.

2. DiNapoli, T. P. (2016). Standards for Internal Control in New York State Government. Available at: http://www.osc.state.ny.us/agencies/ictf/docs/intcontrol_stds.pdf

3. Kanapickienè, R. (2001). Vidaus kontrolès sistemos modelis smulkioms ir vidutinèms imonèms. Daktaro disertacija. Vilnius.

4. King, A. M. (2011). Internal Control of Fixed Assests: a Controller and Auditor's Guide. John Wiley \& Sons. doi: https://doi.org/10.1002/9781118269107

5. Lakis, V. (2007). Audito sistema: raida ir problemos. Vilnius: Viniaus universiteto leidykla.

6. Lietuvos Respublikos vidaus kontrolès ir vidaus audito ịstatymas. (2002). Valstybės žinios, No. 123-5540.

7. Needles, B., Powers, M., Crosson, S. (2011). Principles of Accounting. Cengage Learning.

8. Pickett, K. H. S. (2011). The Essential Quide to Internal Auditing. John Wiley \& Sons, 380.

9. Rupšys, R., Boguslauskas, V. (2007). Measuring Performance of Internal Auditing. Empirical Evidence. Engineering Economics, 55 (5), 9-15.

10. Tarptautiniai vidaus audito profesinès praktikos standartai (vertimas iš anglų kalbos) (2004). Vilnius: Lietuvos vidaus auditorių asociacija.

ГАБРЯВІЧЕНЕ, АУШРА - лектор Маріямпольськой колегії (Маріямполе, Литва)

E-mail: ausra.gabreviciene @ mkolegija.lt, ORCID 0000-0001-7685-1440

ПЯТРОШЕНЕ, БІРУТЕ - лектор Маріямпольськой колегії (Маріямполе, Литва),

E-mail: birute.petrosiene@ mkolegija.lt, ORCID 0000-0002-5160-8249

ШИДЛАУСКЕНЕ, ДАНГОУЛЕ - лектор Маріямпольської колегії (Мариямполе, Литва),

E-mail: danguole.sidlauskiene@mkolegija.lt, ORCID 0000-0002-9154-2934

\section{ВНУТРІШНІЙ АУДИТ І КОНТРОЛЬ У КОМПАНІЇ В КОНТЕКСТІ УПРАВЛІНСЬКОЇ ДІЯЛЬНОСТІ}

Актуальність теми дослідження в тому, що в сучасних умовах актуальною темою $є$ внутрішній аудит і контроль управлінської діяльності. Об'єктом дослідження є внутрішній аудит і контроль у компанії як сучасне складне i суперечливе явище. Предметом дослідження - напрями підвищення ефективності внутрішнього аудиту та контролю у компанії в контексті управлінської діяльності. Мета дослідження - теоретичні та практичні аспекти вивчення внутрішнього аудиту та контролю у компанії та формування концепції ефективності управлінської діяльності. Методологія - аналіз і синтез, абстрагування, індукція і дедукція, перехід від конкретного до абстрактного i навпаки, узагальнення зібраних наукових даних, що допомогли здійснити дане дослідження. На підприємствах, що досягли своїх цілей, зосереджуються на гнучкості та ефективності всіх процесів роботи, а також на оптимальному використанні засобів. 3 цією метою на підприємствах і в організаціях упроваджується 
система внутрішнього контролю, одним із компонентів якої є внутрішній аудит. Основне завдання внутрішнього аудитора - забезпечити незалежну i неупереджену оцінку діяльності організації i розробити рекомендації покращення діяльності. Хоча внутрішній аудит є лише частиною системи внутрішнього контролю суб'єкта господарства, аудит повинен оцінити, чи правильно функціонує система, запропонувати заходи для підвищення ефективності внутрішнього контролю. Від системи внутрішнього контрою багато в чому залежить об'єм роботи аудитора. Добре функціонуюча система внутрішнього контролю зменшує об’єм роботи, пов'язаною 3 аудитом, і ризиками, які дозволяють внутрішньому аудитору більше часу приділяти перспективам розвитку організації. Особлива увага у процесі підвищення ефективності управлінської діяльності повинна приділятися співробітникам, що виконують конкретні функції, включаючи їх у процес удосконалення внутрішнього контролю. Для цього необхідно поглибити знання не тільки керівників, але й всіх співробітників про суть і важливість внутрішнього аудиту та необіхідності досягнення цілей організації.

Ключові слова: внутрішній аудит, внутрішній контроль, управлінська діяльність, аудитор, ефективність, цілі організації

ГАБРЯВИЧЕНЕ, АУШРА - лекТор Мариямпольской коллегии (Мариямполе, Литва)

E-mail: ausra.gabreviciene@mkolegija.lt, ORCID 0000-0001-7685-1440

ПЯТРОШЕНЕ, БИРУТЕ - лектор Мариямпольской коллегии (Мариямполе, Литва),

E-mail: birute.petrosiene@mkolegija.lt, ORCID 0000-0002-5160-8249

ШИДЛАУСКЕНЕ, ДАНГОУЛЕ - лектор Мариямпольской коллегии (Мариямполе, Литва),

E-mail: danguole.sidlauskiene@mkolegija.lt, ORCID 0000-0002-9154-2934

\section{ВНУТРЕННИЙ АУДИТ И КОНТРОЛЬ В КОМПАНИИ В КОНТЕКСТЕ УПРАВЛЕНЧЕСКОЙ ДЕЯТЕЛЬНОСТИ}

Актуальность темы исследования в том, что в современных условиях актуальной темой есть внутренний аудит и контроль в компании в контексте управленческой деятельности. Объектом исследования есть внутренний аудит и контроль в компании как сложное современное и противоречивое явление. Предметом исследования - направления повышения внутреннего аудита и контроля в компании в контексте управленческой деятельности. Цель исследования - теоретические и практические аспекты изучения внутреннего аудита и контроля в компании и формирование концепции эффективности управленческой деятельности. Методология - анализ и синтез, абстрагирование, индукция и дедукция, переход от конкретного к абстрактному и наоборот, обобщение собранных научных данных, которые помогли осуществить Internal audit and control in a company in the context of management activity 
данное исследование. На предприятиях, которые достигают своих целей, сосредотачиваются на гибкости и эффективности всех процесов работы, а также на оптимальном использовании средств. С этой целью на предприятиях и в организациях внедряется система внутреннего контроля, одним из компонентов которой является внутренний аудит. Основная задача внутреннего аудитора - обеспечить независимую и непредвзятую оценку деятельности организации и предъявить рекомендации улучшения деятельности. Хотя внутренний аудит является лишь частью системы внутреннего контроля субъекта хозяйства, аудит дожен оценить, правильно ли функционирует система, предложить меры для повышения эффективности внутреннего контроля. От состояния внутреннего контроля во многом зависит обьем работы аудитора. Хорошо функционирующая система внутреннего контроля уменьшает объем работы, связанной с аудитом, и рисками, которые позволяют внутреннему аудитору больше времени уделять перспективам развитию организации. Особое внимание в процессе повшения эффективности управленческой деятельности должно уделяться сотрудникам, выполняющим конкретные функции, включая их в процесс совершенствования внутреннего контроля. Для этого необходимо углубить знания не только руководителей, но и всех сотрудников о сути и важности внутреннего аудита и необходимости в достижении целей организации.

Ключевые слова: внутренний аудит, внутренний контроль, управленческая деятельность, аудитор, эффективность, цели организации

Стаття рекомендована до публікаџіï д.філософ.н., проф. В.Г.Воронковою (Запоріжжя, Україна)

Надійшла до редколегіï: 20.09.2018

Прийнята до друку: 25.09.2018

(C) Gabrevičienè, Aušra Petrošienè, Birutė Šidlauskienè, Danguolè, 2018 